\title{
The Macrostructure and Register of Chinese, English and Polish School Certificates and University Diplomas
}

\author{
Joanna Grzybek i Aleksandra Matulewska \\ Instytut Językoznawstwa, Uniwersytet im. Adama Mickiewicza \\ ul. Międzychodzka 5, 60-371 Poznań
}

lingualegis@amu.edu.pl

\begin{abstract}
This paper presents the macrostructure of Chinese, English and Polish school certificates and university diplomas (Hughes, Varó 2002) in the aspect of translation. The language and vocabulary used in Chinese, Polish and English certificates and diplomas are researched into. The conclusions are that the historically conditioned differences in legal realities in China, Taiwan, Poland (the impact of the partitions and the Communist regime) and the English-speaking countries affect the structure and contents of such certificates and diplomas. Thus, Polish certificates and diplomas are more similar to British and American ones. However, certificates and diplomas executed in China have different macrostructure (they are in a form of a book). As a consequence, some legal terms and expressions which appear in them do not occur in Polish and English.
\end{abstract}

\section{Introduction}

University diplomas and certificates are one of the most commonly translated legal genres. First, definitions will be given for a diploma and a certificate, and later the focus will be on their macrostructure in the English and Polish languages as documents issued by the Polish and English Institutions (e.g. of Higher Learning) differ in many aspects.

$\boldsymbol{A}$ Diploma is a written document awarding a degree which is issued and given by an educational institution on graduation.

A Certificate is a written document which is signed by the authorized party in order to attest that some act has been done, or some event occurred, or some legal formality has been complied with as well as a document which certifies that the person for whom the certificate is issued has fulfilled some requirements and thus may practice in a field (Black's 1979:205).

\section{Translation Method Used}

In this work the translation model of legal terms described by Kierzkowska (2002) will be applied. This model will be extended for the purpose of this work and translation orientation by Faber, Hjort-Pedersen and Klinge (1996/97:21) will be used.

According to Kierzkowska, in order to translate a text it is necessary to determine: first the function of the source- and target-language texts, second the type of recipients of the target-language text, and third the translative terminological usage imperative which should be applied. Once those three factors are defined it is necessary to choose an appropriate translation method (strategy) that is a coherent plan of action which is adopted and applied by translators 
in order to translate a text in such a way that the needs of the target audience (recipients) are met (Delisle 1999:192).

Faber, Hjort-Pedersen and Klinge (1996/97:21) describe the following two types of translation:

(i) 'a target language orientation. This means that the translator tries to make her text look as much as possible like an original target language document. Consequently, she will orient her translation towards the target language community by imitating the way in which parallel documents are designed in the target language community and by borrowing linguistic material from such parallel texts in her translation purposes. In this case, then, there is little resemblance with the source text.' When this type of orientation in translation will be applied in this paper, it will be marked with the abbreviation TLOT.

(ii) 'a source language orientation. This means that the translator does not make her translation look like an original target language document, but instead orientates her translation towards the source language community by imitating the way in which the source language document is designed and by seeking to transfer semantically or nearliterally the linguistic choices initially mode by the source text producer. This means that there is a much higher degree of resemblance with the source text.' When this type of orientation in translation will be applied in this paper, it will be marked with the abbreviation SLOT.

\section{Translating English University Diplomas into Polish and Chinese}

\section{Heading}

The heading of a diploma is usually the name of the educational institution which issues the document.

Baylor University

College of Arts and Sciences

[TLOT: Uniwersytet Baylor

Kolegium Nauk Humanistycznych i Ścisłych]

[SLOT: Uniwersytet Baylor

College Nauk Humanistycznych i Ścisłych]

[SLOT: Baylor 大学

文学与理学学院]

[TLOT: 贝勒大学

文学与理学学院]

The University of Birmingham

[Uniwersytet w Birmingham]

[SLOT: Birmingham 大学]

[TLOT: 伯明翰大学]

Identification of the issuing authorities (Alcaraz, Hughes 2002:103)

The identification of the diploma issuing institution is usually a part of the first sentence stating at the same time the body authorized to issue the document.

By the authority of the State of Texas vested in the Board of Trustees of Baylor University and...

[Na mocy uprawnienia nadanego przez Stan Teksas Radzie Powierników Uniwersytetu Baylor oraz...]

[根据德克萨斯州(Texas)给贝勒大学董事会的权力。。。]

Academic justification for the award (Alcaraz, Hughes 2002:103)

The academic justification for the award is a statement in which the grounds for the decision are specified.

...upon the recommendation of the Faculty thereof...

[...na wniosek członków Wydziału tej uczelni...]

[。。。根据本大学学院的建议。。。] 
It is hereby certified that (name and surname) having attended the approved postgraduate course of study and having attained the prescribed standard...

[Niniejszym zaświadcza się, że (imię i nazwisko) uczęszczając na akredytowane studia magisterskie i osiągnąwszy wymagany poziom...]

[TLOT: 本人在此证明, (姓名) 已通过硕士学位的课程, 成绩合格。。]

Degree conferred or type of certificate (expressed by a performative verb, or purpose of the certificate) (Alcaraz, Hughes 2002:104)

In this part of a diploma the type of awarded degree is specified or the type of an issued certificate is stated.

The degree of Bachelor of Arts is conferred upon (the name of the diploma holder)

[SLOT: Stopień bakałarza nauk humanistycznych zostaje nadany (nazwisko posiadacza dyplomu)]

[TLOT: Tytuł licencjata nauk humanistycznych zostaje nadany (nazwisko posiadacza dyplomu)]

[授予文学士学位 给(持有毕业证书的人姓名)]

\section{... has been awarded the CERTIFICATE IN EDUCATION ${ }^{1}$ \\ [SLOT: ...przyznaje się CERTYFIKAT W KSZTAŁCENIU] \\ [TLOT: ... wydaje się Świadectwo w zakresie pedagogiki] \\ [授予教育学毕业证书]}

Rights and privileges conferred by the award (Alcaraz, Hughes 2002:104)

This is not an obligatory element of diplomas and does not actually describe the rights and privileges in detail but only indicates that such rights and privileges as prescribed by law are appertained to the diploma.

...with all the rights and privileges appertaining thereto...(Alcaraz, Hughes 2002:104)

[... wraz ze wszystkimi prawami i uprawnieniami z tym związanymi...]

[0。备有所有的权力与特权关于上文。。。]

Place and date of issue (Alcaraz, Hughes 2002:104)

What is characteristic of the place and date of issue is the fact that the year is written in a hyper-formal way (one thousand nine hundred and fifty-eight instead of the everyday nineteen fifty-eight), the month is written in words, and the day is always given as an ordinal number and also may be written in words.

...this 15 th day of May in the year of our Lord one thousand nine hundred and eighty-seven

[TLOT: 15 maja 1987 roku]

[SLOT: dnia 15-tego maja, roku pańskiego tysiąc dziewięćset osiemdziesiątego siódmego]

[TLOT: 一九八七年五月十五日]

... this eighth day of August one thousand nine hundred and fifty-eight

[dnia ósmego sierpnia, tysiąc dziewięćset pięćdziesiątego ósmego roku.]

[TLOT:一九五八年八月八日]

Signature (Alcaraz, Hughes 2002:104)

Apart from the personal signature the position held is always given.

Chairman, Board of Trustees

[Przewodniczący Rady Powierników]

[董事会主席］

President of the University

[SLOT: Prezydent Uniwersytetu]

[TLOT: Rektor Uniwersytetu]

[大学校长]

\footnotetext{
${ }^{1}$ Capital letters in the original
} 


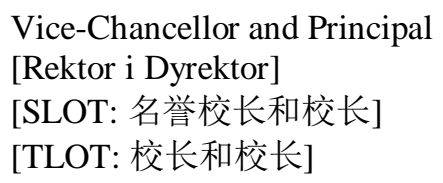

When translating English terms: headmaster, principal, president, chancellor, which concern the head of a school into Chinese translators have to face a problem of polysemy. In Chinese there is only one word for those terms: 校长. If there is a need translators can explain the meaning, for instance Chancellor can be described as: 名誉校长, which means honourable president or principal.

\title{
4 Translating Polish University Diplomas into English and Chinese
}

In Poland two main types of university diplomas may be distinguished, viz:

(i) medical university diplomas and

(ii) other diplomas.

What makes them different is the fact that there is no final grade awarded at a medical university diploma, whereas other higher education institutions' diplomas have an overall grade quoted in them.

\section{Heading}

University diplomas in Poland are in the form of a small two page booklet. The heading is placed on the front cover and it states the kind of diploma.

Dyplom ukończenia studiów

[Diploma of Higher Education]

[高等院校毕业证书]

There are many names of Chinese diplomas of higher education, for instance: 硕士学位证书, 学士学 位证书, 大学毕业证书.

Dyplom ukończenia studiów (odpis)

[Diploma of Higher Education (copy)]

[高等院校毕业证书 (抄件)]

\section{Diploma holder's picture, signature and diploma number}

The holder's picture and a holograph signature appear on the right-hand internal page. There is also a diploma number below the signature, and the number of the official form which includes the information on the Ministry which orders form to be printed.

\section{Identification of the issuing authorities and a subheading}

There is information on the issuing authorities at the top of the right-hand internal page which is followed by a subheading. The identification of the issuing authorities and the subheading are capitalized.

\author{
UNIWERSYTET im. A. MICKIEWICZA W POZNANIU \\ WYDZIAŁ NEOFILOLOGII \\ DYPLOM $^{2}$ \\ [ADAM MICKIEWICZ UNIVERSITY OF POZNAN \\ FACULTY OF MODERN LANGUAGES AND LITERATURE \\ DIPLOMA] \\ [波兹南密茨凯维奇大学 \\ 现代语言与文学系 \\ 毕业证书]
}

\footnotetext{
${ }^{2}$ Capital letters in the original.
} 


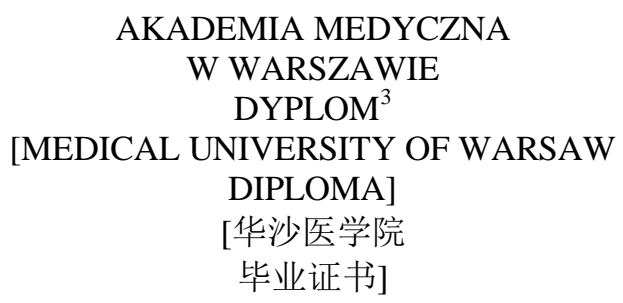

\section{Holder's personal details}

Actually, the holder's personal details are the first part of this one-sentence long document.

Pan(i) Janina Kowalska

Urodzony(a) dnia 10 października 1979 r.

w Kielcach ...

[Mr./Ms. Janina Kowalska

born on October 10th, 1979

in Kielce ...]

[Janina Kowalska,

一九七九年十月十日在凯尔采 (Kielce) 生。。。]

\section{Academic justification for the award}

The academic justification of the award follows the holder's personal details and usually includes the overall grade.

A Medical Diploma:

...po odbyciu studiów na Wydziale Lekarskim w latach 1982-1988 i złożeniu przepisanych egzaminów,...

[...having completed studies at the Faculty of Medicine from 1982 to 1988 and having passed all the prescribed examinations,...]

[TLOT:。。。自 1982 年至 1988 年通过医学专业学业, 符合程考试。。。]

Other Diplomas:

...odbył(a) studia wyższe magisterskie na kierunku filologia w zakresie językoznawstwa $\mathrm{i}$ informacji naukowej $\mathrm{z}$ wynikiem bardzo dobrym $\mathrm{i}$...

[...completed the M.A. higher education studies in the field of philology, specialization in linguistics and information science with the overall grade: very good and...]

[...完成全部博士学业, 文学专业, 语言学和 信息学学科, 成绩优 。。。]

\section{Rights, privileges and a degree conferred by the award}

This part in the case of medical diplomas is more elaborate, while in the case of other diplomas information is usually limited to the degree awarded.

A Medical Diploma:

...uzyskał dnia 22 czerwca 1988 r. tytuł lekarza, stanowiący dowód ukończenia szkoły wyższej i uprawniający do ubiegania się o stopień naukowy doktora oraz prawo wykonywania zawodu w myśl przepisów prawnych obowiązujących w Polskiej Rzeczpospolitej Ludowej.

[...was awarded on June $22^{\text {nd }}, 1988$ the title of physician which is a proof of graduation from a higher education institution and which entitles the holder to apply for the academic degree of a doctor and to petition to be granted the right to practice the profession under the legal regulations being in force in the People's Republic of Poland.]

[ 。 。 - 。八年六月二十二日授予医学硕士学位。本大学毕业证书 持有人毕业高中学校, 能够申请博士学位, 根据波兰共和国法规从事医生职业]

\footnotetext{
${ }^{3}$ Capital letters in the original.
} 
Other Diplomas:

...uzyskał(a) w dniu 31 maja 2000 r. tytuł magistra. [...was granted the title of Master on May 31st, 2000.]

[TLOT: 二000年五月三十一日准予硕士学位]

\section{Signatures of authorized persons, place and date of issue}

At the very end of the right-hand inner page there are usually personal signatures of the Dean and Rector (or alternately their deputies with their positions stated) which are followed by the place and date of the diploma's issue.

\section{Translating Chinese University Diplomas into Polish and English}

University diplomas in China are also in the form of a small two page booklet.

\section{First Page}

\section{National emblem of China and diploma holder's picture}

There is the national emblem of China on a left-hand internal page of some diplomas. It incorporates 4 key elements - yellow stars of China's National Flag, a wheel, a wheat head and a relief of the Tiananmen Gate against the red background. The diplomas with national emblem contain the diploma holder's picture on the right-hand internal page. If there is no emblem on the internal page, then the diploma holder's picture appears on the left-hand internal page.

\section{Heading}

The heading of a diploma is usually the name of the educational institution which issues the document or the kind of a diploma.

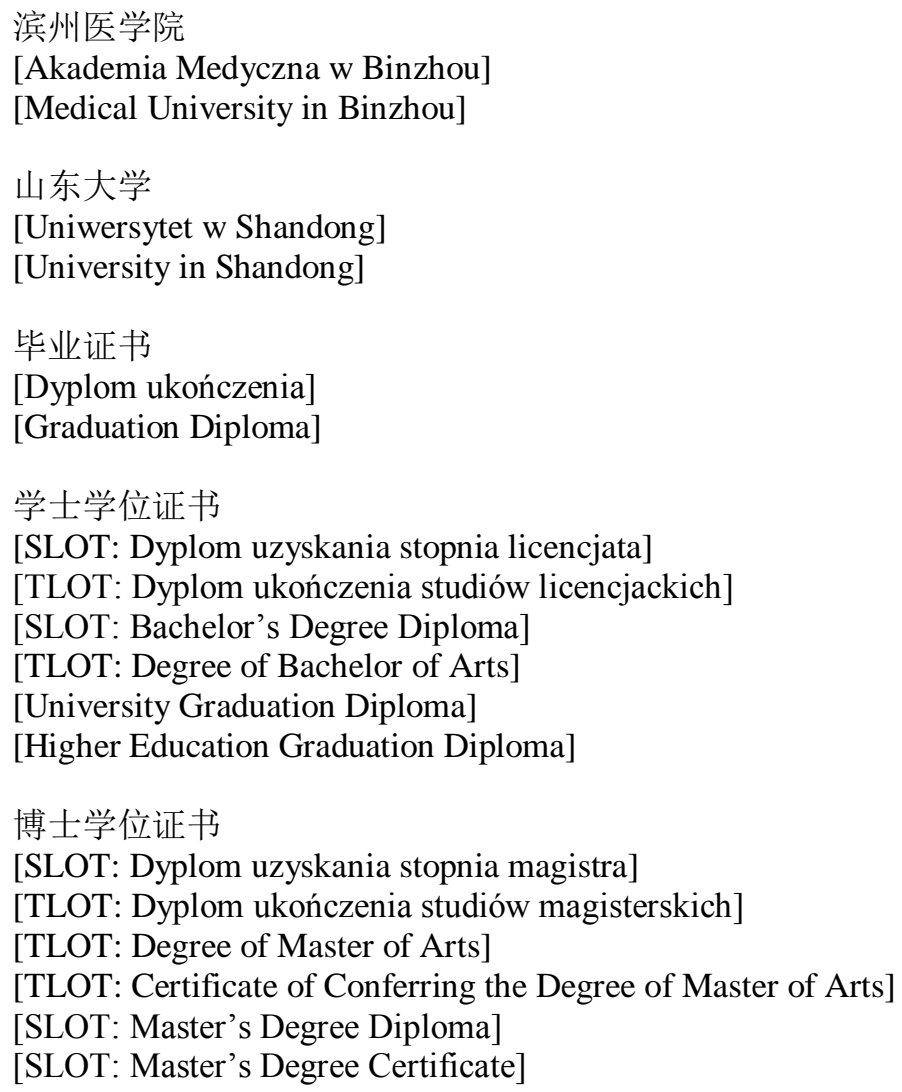




\section{Second Page}

\section{Holder's personal details}

Actually, the holder's personal details are the first part of this one-sentence long document.

学生陈天高

[TLOT: Student Chen Tiangao]

[TLOT: Student's Name: Chen Tiangao]

性别男

[Płeć: mężczyzna]

[Sex: male]

\section{系山东省青岛市人}

[TLOT: mieszkaniec prowincji Shandong, miasta Qingdao]

[TLOT: inhabitant of the Shandong province, the city of Qingdao]

一九六七年四月生

[urodzony w kwietniu 1967 r.]

[TLOT: born in April 1967]

[SLOT: Student Chen Tiangao urodzony w kwietniu 1967 roku jest mieszkańcem prowincji Shandong, miasta Qingdao]

[SLOT: Male student Chen Tiangao born in April 1967 is the inhabitant of the Shandong province, the city of Qingdao]

Academic justification for the award (Alcaraz, Hughes 2002:103)

The academic justification for the award is a statement in which the grounds for the decision are specified.

自 1998 年 11 月至 2001 年 12 月完成了山东大学自考英语专业三年制本科学习计划, 业已毕业。

[Od listopada 1998 roku do grudnia 2001 roku odbył studia na Uniwersytecie w Shandong ze specjalizacją w języku angielskim i ukończył je uczęszczając przez 3 lata na zajęcia zgodne z programem.]

[attended a 3-year course in English Studies at the Shandong University from November 1998 till December 2001 and having completed compulsory curriculum graduated from it]

于一九八三年九月六日入本院医学专业, 学习五年, 按教学计划完成全部学业, 成绩及 格, 准予毕业。

[6-tego września 1983 roku zaczął uczęszczać na zajęcia z medycyny i po 5 latach nauki zgodnie z programem nauczania i zdając egzaminy ukończył studia]

[on 6 September 1983 he started attending the medical course and having completed 5-year long studies in compliance with the curriculum and having passed all the prescribed examinations graduated from the University]

在我教中医内科学学科 (专业) 已通过博士学位的课程考试和论文答辩, 成绩合格。 [Odbył studia magisterskie z zakresu tradycyjnej medycyny chińskiej ze specjalnością w zakresie chorób wewnętrznych oraz obronił pracę magisterską, z wynikiem pozytywnym] [SLOT: completed master studies in the field of traditional Chinese medicine with the specialization in internal disease (internal medicine) and successfully defended his master thesis examination]

[TLOT: completed master studies in Chinese medicine with the specialization in internal medicine and passed his master thesis examination] 


\section{Degree conferred}

In this part of a diploma the type of awarded degree is specified.

根据《中华人民共和国学位条例》的规定，

[W zgodzie przepisami Chińskiej Republiki Ludowej o tytułach akademickich]

[In compliance with the law of the Chinese People's Republic on university degrees]

授予医学博士学位

[SLOT: uzyskał stopień magistra medycyny]

[SLOT: was admitted to the Degree of the Master of Medicine]

授予文学学士学位

[uzyskał stopień licencjata literatury]

[was admitted to the Degree of Bachelor of Arts in literature]

授予医学学士学位

[SLOT: uzyskał stopień licencjata medycyny]

[SLOT: was awarded the degree of Bachelor of Medicine]

Place and date of issue (Alcaraz, Hughes 2002:104)

山东大学

[Uniwersytet w Shandong]

[University in Shandong]

山东中医药大学

[Uniwersytet Tradycyjnej Medycyny Chińskiej w Shandong]

[Traditional Chinese Medicine in Shandong]

学位评定委员会主席（章）

[Przewodniczący Komitetu nadającego tytuły akademickie (pieczątka)]

[President of the Committee conferring university degrees (seal)]

二0 0 三年七月十五 日

[SLOT: 2003 rok, miesiąc 7-my, dzień 15-ty]

[TLOT: 15 lipca 2003 r.]

[SLOT: 2003, the seventh month, the fifteenth day]

[TLOT: 15 July 2003]

\section{Certificate Number}

There is also the certificate number.

证书编号：104758016395

[Numer dyplomu : 104758016395]

[Diploma number: 104758016395]

\section{Concluding Remarks on Translation of University Diplomas}

English, Chinese and Polish university diplomas and certificates differ. Not only their structures, but their contents differ as well. The heading of an English diploma has information about the higher education institution in question, whereas the heading of a Polish diploma gives information about the type of document issued. Some headings of Chinese diplomas, on the other hand, give the name of the institution, others inform about the type of certificate and the title conferred. The identification of the issuing authorities in English documents is given as a part of the first sentence, while in Polish documents the name of the institution is given at the beginning of the document and it is a separate part of the document written in a similar way as in the addresses but without a street and a post code. Thus, it forms a subheading together with the name of the diploma. Polish documents contain much more detailed information 
on the holder's personal details, including date and place of birth often with the holder's picture and signature. On the other hand, English documents usually give only the holder's name and surname. Finally, Chinese diplomas inform about the month and year of birth but not about the day. Moreover, the parts concerning the degree, rights and privileges conferred differ. The passive voice is used in English documents and active voice is used in Polish and Chinese ones. The dates are also written differently as in English documents the date is given in words not in numbers, while in Polish documents usually only the name of a month is given in words. In Chinese university diplomas a year is given first and it is followed by a month and sometimes a day.

To sum up, in the event of translating university diplomas and certificates it is usually necessary to apply source-language orientation. Thus, the differences are preserved. However, if the target-language translation is required for some reasons, then it seems advisable to change passive voice into active voice, to find connotative (target-language oriented) equivalents for the degrees conferred, etc.

\section{Translating English School Certificates into Polish and Chinese}

\section{Heading}

The heading of a school certificate is different from the university diploma as the heading contains not only the name of the institution which issues a certificate but also its type.

\section{JOINT MATRICULATION BOARD}

SCHOOL CERTIFICATE ${ }^{4}$

[SLOT: Świadectwo szkolne wydane przez Wspólną Radę Immatrykulacyjną]

[注册入学董事会毕业证]

Secondary School Honour Graduation Diploma

[SLOT: Dyplom ukończenia szkoły średniej z wyróżnieniem]

[TLOT: Świadectwo ukończenia szkoły średniej z wyróżnieniem]

[SLOT: 通过高中奖励毕业证]

\section{Diploma holder's personal details}

The holder's personal details include name and date of birth. The date of birth is usually given in the following way: the day is a cardinal number, the month is written in words and the year is also a cardinal number.

This diploma is granted to (name) a student of Madawaska Valley District High School who ...

[Niniejszy dyplom zostaje wydany (nazwisko), uczniowi szkoły średniej w okręgu Doliny Madawaska, który/która...]

[SLOT: 本毕业证是签发的给(姓名), Madawaska Valley 地区高中学学生，。。。]

(name) born on 12 August $1933 \ldots$

[(nazwisko) urodzony/urodzona 12 sierpnia 1933...]

[(姓名)一九三三年，八月十二日生。。。]

\section{Academic justification for the award and purpose of the certificate}

Attended Aireborough Grammar School, Yeadon and was awarded the School Certificate of the joint matriculation Board on July, 1948, having satisfied the examiners in the examination as a whole and having attained the standard shown in the following eight subjects: ...

[TLOT: Uczęszczał(a) do Liceum Aireborough w Yeadon i uzyskał(a) świadectwo szkolne wydane przez wspólną Radę immatrykulacyjną w lipcu 1948 r. po tym jak spełnił(a) wymagania egzaminatorów podczas całościowego egzaminu oraz po uzyskaniu zgodnie z wymogami niniejszych ocen z następujących ośmiu przedmiotów:...]

\footnotetext{
${ }^{4}$ Capital letters in the original.
} 
[她/他在 Yeadon入Aireborough 高中学校的学业, 成绩及格, 一九四八年七月受到了被 注册入学董事会签发的毕业证书。下面她/他的毕业成绩清单：。。]

...has fulfilled the requirements for the Secondary Honour Graduation Diploma in accordance with the regulations of the Ministry of Education, Ontario...

[...spełnił(a) wymagania konieczne do uzyskania dyplomu ukończenia szkoły średniej z wyróżnieniem na mocy przepisów Ministerstwa Edukacji, w Ontario, ...]

[TLOT:。。经审核符合《安大略 (Ontario) 教育部 通过高中学毕业条例》规定, 授 予通过高中学校毕业证书，。。。]

\section{Scale of and final grades}

The grades are usually composed of a list of subjects taken and grades awarded. However, there are certificates in which an overall-performance grade is given. Furthermore, there is also a scale of passing or passing and failing grades supplied.

(the standards of award in individual subjects are Very Good, Credit, Pass)

[(skala ocen pozytywnych dla poszczególnych przedmiotów jest następująca: bardzo dobry, dobry, dopuszczający)]

[SLOT: (成绩及格关于单一的课分为：很好，好，许可三等)]

[TLOT: (成绩及格分为：优, 良, 合格三等)]

\section{Place and date}

The place and date is written either in the same way as in the case of university diplomas or in the way given below.

Dated at Barry's Bay, Ontario the $30^{\text {th }}$ day of June 1978

[Dnia 30-tego czerwca, 1978 r., w Ontario, Barry's Bay]

[一九七八年，六月三十日，Ontario， Barry's Bay]

\section{Signature}

The signature is very similar to the equivalent part of diplomas. There are personal signatures of persons followed by the positions they hold. If a person is signing a document on someone else's authorization, then the expression signed on behalf of followed by the authorizing body's name will be found on the document.

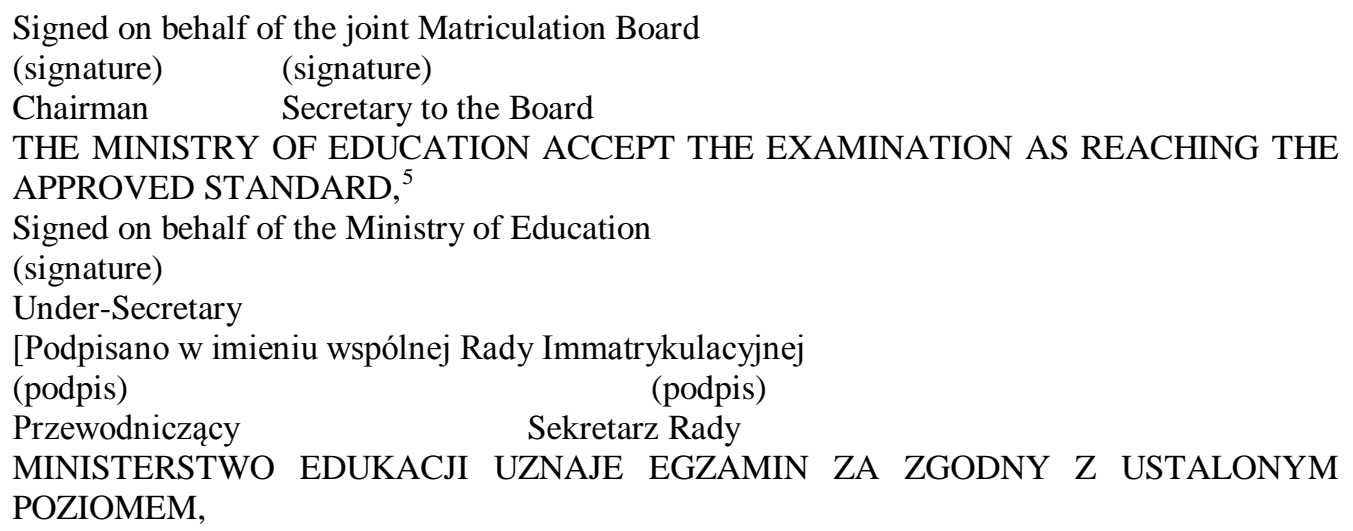

${ }^{5}$ Capital letters in the original. 


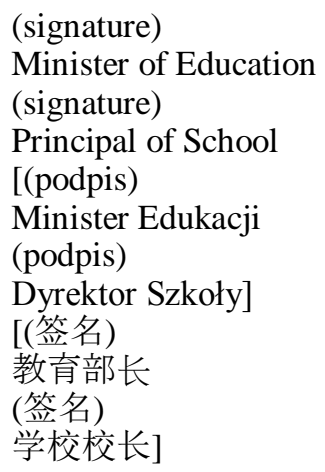

\section{Translating Polish School Certificates into English and Chinese}

Most school certificates are two page long documents. Here a secondary comprehensive school graduation certificate [świadectwo dojrzałości liceum ogólnokształcacego], which is a four page long document, will be described. In comparison with other school certificates this certificate has two additional pages which contain information on the graduation examination and vocational subjects taken, or special achievements of the secondary school student. The information included on the first two pages is consistent with other school certificates. There are only minor differences e.g. the holder's photograph may be found only on the graduation certificate.

\section{First Page \\ Heading}

The heading of the Secondary Comprehensive School Graduation Certificate is capitalized and it is the type of a certificate.

\section{ŚWIADECTWO DOJRZAŁOŚCI LICEUM OGÓLNOKSZTAŁCĄCEGO ${ }^{6}$ [SECONDARY COMPREHENSIVE SCHOOL GRADUATION CERTIFICATE] [TLOT: 普通高级中学毕业证书]}

\section{Diploma holder's picture and personal details}

The diploma holder's personal details and a picture are given in an identical manner as in the case of university diplomas. What is characteristic of the date is the fact that the word dnia is followed by the cardinal number of a day, then there is a month given in words and a year again given as a cardinal number followed by and abbreviation $r$. standing for rok [year].

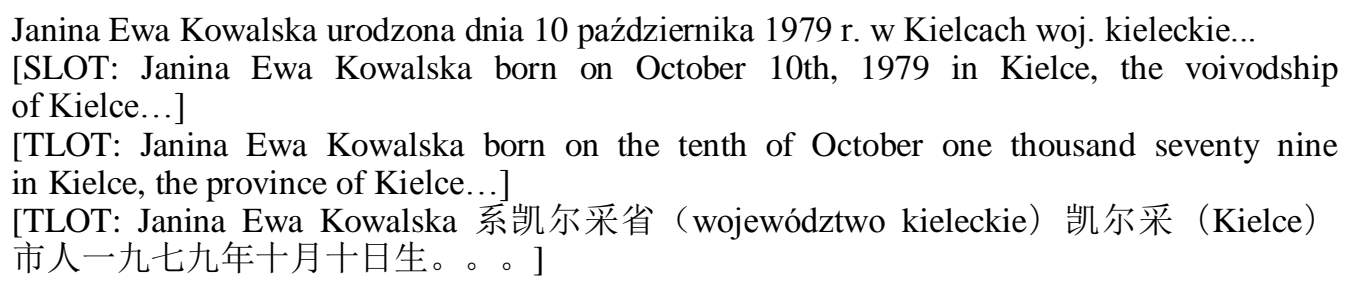

\section{Justification for the award and identification of the issuing authorities}

The justification for the award which is given in a school certificate is a part of the same sentence which also includes the identification of issuing authorities, the type of curriculum, the graduation school year and the date of the taken graduation examination.

\footnotetext{
...ukończyła z wyróżnieniem naukę w II Liceum Ogólnokształcącym im. Jana Śniadeckiego w Kielcach woj. kieleckie w klasie o profilu humanistycznym literacko-reporterskim w r. szk. 1994/95 oraz złożyła egzamin dojrzałości w dniu 31 maja 1995 r.

[... graduated with merit from the 2nd Secondary Comprehensive School of Jan Śniadecki in Kielce, the voivodship of Kielce, in a class of humanistic literary and journalistic curriculum in the school year 1994/95 and she took the graduation examination on May $\left.31^{\text {st }}, 1995.\right]$
}

\footnotetext{
${ }^{6}$ Capital letters in the original.
} 
[TLOT:。。一九九五年在系凯尔采省（województwo kieleckie）凯尔采（Kielce）市 第二所普通高中学 (II Liceum Ogólnokształcące im. Jana Śniadeckiego w Kielcach) 文学 和新闻事业专业完成全部学业。一九九五年五月三十一日参加毕业考试, 成绩及格。]

\section{Rights and privileges conferred by the award}

A secondary school graduation certificate gives information about the education level of the holder and rights appertained to the certificate, that is the right to apply for admission to universities or other institutions of higher learning.
Świadectwo jest dokumentem stwierdzającym posiadanie wykształcenia średniego ogólnego i uprawnia do ubiegania się o przyjęcie na studia w szkołach wyższych.
[This certificate is a document which states that the holder has secondary education and authorizes him/her to apply for admission to Institutions of Higher Education.]
[TLOT:本证书证明持有人毕业高中学校, 能够参加高考]

\section{Place and date of issue}

What is characteristic of official documents such as university diplomas and school certificates is the fact that the cardinal number representing the day follows the word dnia, the name of a month is written in words not numbers, and the year is always followed by the abbreviation $r$. (standing for year). The place is given usually at the very beginning and separated from the date with a comma.

Kielce, dnia 7 czerwca 1995 r.

[Kielce, on June 7th, 1995.]

[SLOT: Kielce, 六月七日, 一九九五年]

[TLOT: 凯尔采, 一九九五年六月七日]

\section{Certificate number, signature of authorized person}

At the bottom of the first page there are also: (i) the certificate number, (ii) the official round seal of the school, (ii) the signature of the School Principal, and (iv) the rectangular seal of the School Principal.

\section{Second Page}

\section{Final grades for subjects included in the curriculum}

There are final grades for the listed subjects included in the compulsory curriculum given on the second page of the Certificate. At the bottom of the page there are (i) a scale of grades used nationwide and (ii) the signature of a Class Master.

The scale of grades is the following:

\begin{tabular}{|ccc|}
\hline Celujący & A/excellent & 优秀 \\
\hline Bardzo dobry & B+/very good & 优 \\
\hline Dobry & B/good & 良 \\
\hline Dostateczny & C/satisfactory & 及格 \\
\hline Mierny & D/pass & 不好 \\
\hline Niedostateczny & E/F.//fail & 不及格 \\
\hline
\end{tabular}

\section{Third Page}

The third page gives information about the maturity exam details such as (i) the justification for awarding the certificate and the grades awarded in subjects examined during the maturity examination, as well as (ii) signatures of the maturity examination board members.

\section{Fourth Page}

The last page of the certificate may be left blank or may be filled with some data concerning special achievements of the student such as participation in competitions and the ranking position achieved in them or extracurricular subjects taken by the student. There is also the signature of a class master there. 


\section{Translating Chinese School Certificates into Polish and English}

The Chinese school certificates are four page long documents in a form of a book. Here a senior secondary school graduation certificate [毕业 证 书], which is a four page long document, wil lbe described. In comparison with primary school certificate this certificate contains information on the graduation examination of compulsory subjects and elective subjects taken. The Chinese education system is examinations and results-focused. Examinations are taken at the end of junior secondary school and at the end of senior secondary school. There is also a university entrance examination. The information included on the first two pages is consistent with other school certificates, they contain name and seal of the institution which issues a certificate, holder's photograph and personal details.

\section{First Page}

\section{Heading}

The heading of a school certificate is usually the name of the educational institution which issues the document.

\section{四川省普通高中 \\ 毕业证书 \\ [SLOT: Świadectwo Ukończenia] \\ [Graduation Certificate]}

[SLOT: Powszechna Szkoła Średnia w Sichuanie]

[TLOT: Powszechna Szkoła Średnia w prowincji Syczuan]

[SLOT: Comprehensive Secondary School in Sichuan]

[TLOT: Comprehensive Secondary School in the Sichuan province]

\section{Diploma holder's picture}

The holder's picture appears on the left-hand internal page.

\section{Certificate number}

There is also a year of issuing a certificate below the picture, certificate number and the number of the holder's status as a student.

（2003 年）毕字第 293 号

[2003 rok, nr świadectwa: 293]

[2003, certificate no. 293]

学籍号: 03010027293

[Nr ucznia: 03010027293]

[SLOT: student number: 03010027293]

[TLOT: student registration number: 03010027293]

\section{Identification of the issuing authorities}

The identification of the certificate issuing institution is usually at the bottom of the left-hand internal page which is followed by a seal. The seal is red and contains information about the place of issuing a certificate and the name of the body authorized to issue the document.

\section{Second Page}

\section{Diploma holder's personal details}

The holder's personal details include name, sex and age. Student's sex is given, because of the fact, that some male names are the same as female ones. 
学生黄天天

[Uczeń: Zong Tiantian]

[SLOT: Student: Zong Tiantian]

[TLOT: Student's Name: Zong Tiantian]

性别女

[Płeć: kobieta]

[Sex: female]

年龄 18 岁,

[Wiek: 18 lat]

[Age: 18 (years old)]

\section{Place and Date}

系四川省（直辖市, 自治区）成都市（州）县（市, 区）人,

[SLOT: należąca do prowincji Sichuan (miasta wydzielonego , regionu autonomicznego), miasta Chengdu (rejonu), mieszkaniec okręgu ... (miasta, regionu)]

[TLOT: należąca do prowincji ( miasta wydzielonego, regionu autonomicznego): Syczuan, miasta (rejonu) Chengdu, mieszkanka okręgu (miasta, regionu) ...]

[from the province (separated city/autonomous region) of Sichuan, the city (region) of Chengdu a female inhabitant of the district (city/region)of ...]

于二 00 三年五月在本教高中修业期满, 成绩及格, 准予毕业。

[W maju 2003 roku, zakończyła naukę w tejże szkole średniej, zdała egzamin i ukończyła szkołę ]

[SLOT: She completed the course in May 2003 having passed the examination as a result of which she graduated from that School]

\section{Signature}

学校 (章)

[Szkoła (pieczątka)]

[School's Seal]

校长 (章)

[Dyrektor szkoły (pieczątka)]

[SLOT: School Director]

[TLOT: School Principal]

二00三年五月三十日

[SLOT: 2003 rok, 5-ty miesiąc, dzień 30-ty]

[TLOT: 30 maj 2003 r.]

[SLOT: the thirtieth day of the fifth month of 2003]

[30 May 2003]

\section{$\underline{\text { Third Page }}$}

Final Grades for Compulsory and Optional Subjects

There are final grades for the listed subjects included in the compulsory and extracurricular subjects. This part is usually composed of a list of subjects taken and grades awarded. The list is in a form of a table (see below).

毕业成绩

[Oceny końcowe]

[Final Grades] 


\begin{tabular}{|c|c|c|c|}
\hline 科（项 ）目 & [Przedmiot] & 成绩 & [Ocena] \\
\hline 政治 & [TLOT: wiedza o społeczeństwie] & 优 & [TLOT: bardzo dobry] \\
\hline 语文 & [język i literatura] & 优 & [TLOT: bardzo dobry] \\
\hline 数学 & [matematyka] & 优 & [TLOT: bardzo dobry] \\
\hline 外语 & [język obcy] & 优 & [TLOT: bardzo dobry] \\
\hline 物理 & [fizyka] & 合格 & [TLOT: dostateczny] \\
\hline 化学 & [chemia] & 优 & [TLOT: bardzo dobry] \\
\hline 生物 & [biologia] & 良 & [TLOT: dobry] \\
\hline 历史 & [historia] & 良 & [TLOT: dobry] \\
\hline 地理 & [geografia] & 优 & [TLOT: bardzo dobry] \\
\hline 生物实验 & [test $\mathrm{z}$ biologii] & 良 & [TLOT: dobry] \\
\hline 化学实验 & [test $\mathrm{z}$ chemii] & 合格 & [TLOT: dostateczny] \\
\hline 物理实验 & [test z fizyki] & 合格 & [TLOT: dostateczny] \\
\hline 劳动技术 & [TLOT: technika] & 合格 & [TLOT: dostateczny] \\
\hline 操行等级 & [zachowanie] & 合格 & [TLOT: dostateczne] \\
\hline 信息技术 & [informatyka] & 良 & [TLOT: dobry] \\
\hline 选修科 (项 ) 目 & [przedmiot wybrany] & 成绩 & [Ocena] \\
\hline 书法 & [kaligrafia] & 优 & [TLOT: bardzo dobry] \\
\hline 音乐 & [muzyka] & 优 & [TLOT: bardzo dobry] \\
\hline
\end{tabular}

\begin{tabular}{|c|c|c|c|}
\hline 科（项）目 & [Subject] & 成绩 & [Grade] \\
\hline 政治 & [TLOT: social science] & 优 & [TLOT: A][very good ] \\
\hline 语文 & [language and literature] & 优 & [TLOT: A] \\
\hline 数学 & [mathematics] & 优 & [TLOT: A] \\
\hline 外语 & [foreign language] & 优 & [TLOT: A] \\
\hline 物理 & [physics] & 合格 & [TLOT: C][satisfactory/pass] \\
\hline 化学 & [chemistry] & 优 & [TLOT: A] \\
\hline 生物 & [biology] & 良 & [TLOT: B] [good] \\
\hline 历史 & [history] & 良 & [TLOT: B] \\
\hline 地理 & [geography] & 优 & [TLOT: A] \\
\hline 生物实验 & [test in biology] & 良 & [TLOT: B] \\
\hline 化学实验 & [test in chemistry] & 合格 & [TLOT: C] \\
\hline 物理实验 & [test in physics] & 合格 & [TLOT: C] \\
\hline 劳动技术 & [TLOT: technology computer science & 合格 & [TLOT: C] \\
\hline 操行等级 & [conduct] & 合格 & [TLOT: C] \\
\hline 选修科 (项) 目 & [selected subject] & 成绩 & [Grade] \\
\hline 书法 & [calligraphy] & 优 & [TLOT: A] \\
\hline 音乐 & [music] & 优 & [TLOT: A] \\
\hline
\end{tabular}




\section{Fourth Page}

The last page of the certificate is filled with an explanation concerning the school certificate. The most important information refers to compulsory and extracurricular subjects and the scale of grades. In China there are four grades awarded for the studied subjects:

\begin{tabular}{|ccc|}
\hline 优 & celujący/wybitny/bardzo dobry & excellent/outstanding/A \\
\hline 良 & bardzo dobry/dobry & good/B \\
\hline 及格/合格 & dostateczny/zadawalajacy & pass/C \\
\hline 不及格/不合格 & niedostateczny & fail/D \\
\hline and also four grades awarded for a moral conduct of a student: \\
\hline 优秀 & wzorowe/ bardzo dobry & excellent \\
\hline 良好 & bardzo dobre & very good \\
\hline 及格 & dobre & good \\
\hline 不及格 & nieodpowiednie/naganne & Improper/ reproacheful \\
\hline
\end{tabular}

\section{Concluding Remarks on Translation of School Certificates}

The differences between Chinese, English and Polish school certificates are even more visible that in the event of university diplomas and certificates. First of all, Polish documents of that type are usually much longer than the English and Chinese ones. What is more, the scales of grades and compulsory subjects differ to some extent. Chinese school certificates are in a form of a book similarly as Polish university diplomas.

Most certificates and diplomas are forms which are filled in with personal data. While translating from English and Chinese into Polish, translators should pay special attention to the seven cases which exist in Polish. Contrary to Polish and English certificates and diplomas, all types of Chinese diplomas give the sex of a diploma holder.

Taking all that into consideration, the translation strategy chosen (which is described in the introductory part of this paper in detail) will determine the choice of equivalents. If a translator is dealing with a school certificate or diploma which is mentioned in a novel (genre: popular fiction) then dynamic equivalents are probably the best solution so the scale of grades could probably be the following:

\begin{tabular}{|ccc|}
\hline Bardzo dobry & A & 优 \\
\hline Dobry & B & 良 \\
\hline Dostateczny & C & 合格 \\
\hline Mierny & D & 不好 \\
\hline Niedostateczny & E / F. & 不及格/不合格 \\
\hline
\end{tabular}

In the case of Chinese and older Polish medical university diplomas grades which may be obtained are pass or fail. If the grade is fail, then of course, no diploma is issued.

If the Polish and Chinese certificates or diplomas are translated because someone wants to apply for a job abroad then in the case of university diplomas the strategy may even require to make a translator's commentary concerning the nationwide scale of grades (as on school certificates there is the scale of grades given). In the case of English certificates and diplomas on which there is no scale of grades the same technique may be applied. Different ways of writing the date shall also be taken into consideration. The function of university diplomas and other certificates is:

(i) to prove certain qualifications (taking into consideration the purpose of the translation product the source language oriented translation should be applied then), or

(ii) to inform about the educational system of a given country (thus, the target language translation should prevail in that case). 
In the wake of Polish membership in the European Union the former is definitely the most common. That is why, it seems most reasonable to make the translation source-language oriented in order to stress the differences between the educational systems and not to be misleading about the qualifications acquired.

While translating university and vocational degrees and titles it is necessary to apply the rules imposed on translators by authorized bodies, use equivalents published in official journals or established on the basis of bilateral and multilateral international agreements. If there are no such sources which may be relied on, then it is necessary for translators to coin a new term in the target language in such a way that it is not misleading. Thus, the Italian dottore should rather be translated as Polish magister than doktor. What is more, it is highly advisable to supply the original title or degree in brackets after the target language translation. Furthermore, translators should apply the rules stated by the International Organization for Unification of Terminological Neologism [Międzynarodowa Organizacja Unifikacji Neologizmów Terminologicznych] or the United Nations, etc. if possible ${ }^{7}$ (Kierzkowska 1991:28-31).

\footnotetext{
${ }^{7}$ More information: IFTB/IOUTN/MOUNT ul. Szturmowa 4 (office: 510), 02-678 Warsaw, Poland. Tel/Fax: +48 22843 5573
} 


\section{Bibliography}

Alcaraz, E., Hughes, B. 2002. Legal Translation Explained. Manchester: Svol. Jerome Publishing.

Black's Law Dictionary. 1979. Fifth Edition. United States of America: St Paul Minn. West Publishing Co.

Black's Law Dictionary. 2004. Eighth Edition. Garner Brayan A. (ed.). United States of America: Thomson Wesvol.

Du Jinbang, 2003 Falü yuyan xue, Shanghai waiyu jiaoyu chubanshe, Shanghai 2004.

Faber, D., Hjort-Pedersen, M., Klinge, A. 1996/1997. Introduction to English Legal Language. BA Sproglinien (nonpublished materials).

Garner, B. A. 2001. Legal Writing in Plain English. A Text with Exercises. Chicago/London: University of Chicago Press. Garner, B. A. 2002. The Elements of Legal Style. Oxford/New York: Oxford University Press.

Hanyu falü cidian. 1999. Beijing: Falü chubanshe.

He Zhuzi. 2003. Zui xinde falü zhuanye yingyu, Beijing: Jixie gongye chubanshe.

Kierzkowska, D. (ed.). 1998. Selection of English Documents. Warszawa: Wydawnictwo TEPIS.

Kierzkowska, D. 1991. Kodeks thumacza sadowego. Warsaw: Polish Society of Economic, Legal, and Court Translators TEPIS.

Kierzkowska, D. 1993. POLTERM Polish System of Unified Terminology. International Forum of Legal Translation 1992. Proceedings. Warsaw: Polish Society of Economic, Legal, and Court Translators TEPIS.

Kierzkowska, D. 2002. Ttumaczenie prawnicze. Warsaw: TEPIS Publishing House.

Matulewska, A. 2005. Lingua Legis in the Aspect of Translation. Adam Mickiewicz University (non published doctoral dissertation written under the supervision of Professor Jerzy Bańczerowski).

Poznański, J. (ed.). 1998. Dokumenty polskie. Wybór dla tlumaczy sądowych. Warszawa: Wydawnictwo TEPIS.

von Singer H. 1994. Einführung in das chinesische Recht, München: Verlag C.H. Beck.

Yu Jiang. 2001. Jindai Zhongguo faxue yuci de xingcheng yu fazhan, Beijing: Zhongguo zhengfa daxue chubanshe. 